\title{
18F-FDG-PET/CT in Initiation and Progression of Inflammation and Infection
}

\author{
Enfeksiyon ve Enflamasyonun Oluşum ve Gelişim Sürecinin 18F-FDG-PET/BT Kullanılarak \\ İlenmesi
}

\author{
Türkan Ertayl, Mine Sencan Eren', Meral Karaman2, Gülgün Oktay3, Hatice Durak' \\ ' Dokuz Eylül University Faculty of Medicine, Department of Nuclear Medicine, Izmir, Turkey \\ 2Dokuz Eylül University Faculty of Medicine, Department of Clinical Microbiology, Izmir, Turkey \\ 3Dokuz Eylül University Faculty of Medicine, Department of Clinical Biochemistry, Izmir, Turkey
}

\begin{abstract}
Objective: Detection/localization of infection and inflammation is important for the initiation of correct treatment as well as its maintenance. Nuclear medicine imaging methods play an important role in determining infection and inflammation. 18F-2'-deoxy-2-fluoro-d-glucose (18F-FDG) positron emission tomography/computed tomography (PET/CT) is highly sensitive in such cases when used with tomographic cross-sections. In this study, the development and progression of infection and inflammation were monitored on rats by using $18 \mathrm{~F}-\mathrm{FDG}$ via PET/CT.

Methods: Sterile and infected abscesses were formed on rats using turpentine and S. aureus, respectively. For evaluation of the formation and progression of the abscess, $18 \mathrm{~F}-\mathrm{FDG}$ was injected into the rats and they were imaged by PET/CT at intervals of twenty-four hours for five days. Maximum standard uptake value (SUV $\max$ ) of $18 \mathrm{~F}-\mathrm{FDG}$ was calculated.

Results: The highest activity involvement was seen on the first day of abscess formation. On the first day, SUV max of the $S$. aureus abscess was $3.9 \pm 0.9$ while in the sterile abscess $S U V_{\text {max }}$ in the first day was $2.2 \pm 0.8$. ${ }^{18 F-F D G}$ uptake decreased day by day and it reached the background level on the fourth and fifth days. There were statistically significant differences between $S$. aureus and sterile abscess, and between sterile abscess and background activity in terms of SUV $V_{\max }$ values during the first three days $(p<0.05)$. On the fourth and fifth days, there was no statistically significant difference between $S$. aureus and sterile abscess, and between sterile abscess and background activity ( $p>0.05)$.

Conclusion: The results demonstrated that the SUV $V_{\max }$ value for ${ }^{18}$ F-FDG can be useful in the early differentiation of sterile and infected abscess. In addition, 18F-FDG-PET imaging has the advantage of local availability of equipment and labeled agents leading rapid diagnosis of differentiation of infection and inflammation.

Keywords: Abscess, infection, inflammation, S. aureus, turpentine, positron emission tomography/computed tomography, 18F-2'-deoxy-2-fluoro-d-glucose, rat
\end{abstract}

\section{Öz}

Amaç: Enfeksiyon ve enflamasyonun tespit edilmesi ve yerinin belirlenmesi, doğru tedavinin başlanması ve hastaların bakımı için birincil öneme sahiptir. Enfeksiyon ve enflamasyonu saptamada nükleer tıp görüntüleme yöntemleri önemli rol oynar. 18F-2'-deoksi-2-fluoro-d-glukoz (18F-FDG) pozitron emisyon tomografisi/bilgisayarlı tomografi (PET/BT) yüksek duyarlı̆̆a sahiptir. Bu çalışmada enfeksiyon ve enflamasyonun oluşum ve gelişim süreci 18F-FDG ile PET/BT kullanılarak izlendi.

Address for Correspondence: Türkan Ertay MD, Dokuz Eylül University Faculty of Medicine, Department of Nuclear Medicine, İzmir, Turkey Phone: +90 2324124280 E-mail: turkan.ertay@gmail.com Received: 20.01.2015 Accepted: 13.03.2017 


\section{Öz}

Yöntem: Terebentin ve $S$. aureus kullanılarak ratlarda steril ve enfekte apse oluşturuldu. Apsenin oluşum ve gelişim sürecini değerlendirmek için ratlar 24 saatlik aralar ile 5 gün 18F-FDG enjekte edilerek PET/BT ile görüntülendi. 18F-FDG'nin maksimum standart uptake değeri (SUV maks $)$ hesaplandı.

Bulgular: En yüksek aktivite tutulumu apse oluşumunun ilk gününde görüldü. illk gün $S$. aureus için $S U V_{\text {maks }} 3,9 \pm 0,9$ iken steril apse için $S U V_{\text {maks }} 2,2 \pm 0,8$ idi. ${ }^{18 F-F D G ~ t u t u l u m u ~ g u ̈ n d e n ~ g u ̈ n e ~ a z a l ı k e n ~ d o ̈ r d u ̈ n c u ̈ ~ v e ~ b e s ̧ i n c i ~ g u ̈ n l e r d e ~ z e m i n ~ a k t i v i t e ~}$

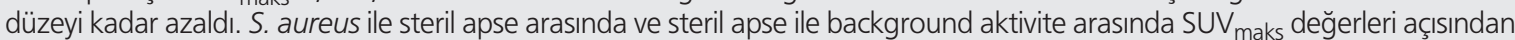
ilk üç gün görüntülerde istatistiksel olarak anlamlı fark vardı $(p<0,05)$. Dördüncü ve beşinci günlerde ise $S$. aureus ile steril apse arasında ve steril apse ile kontrol arasında istatistiksel olarak anlamlı bir fark yoktu $(p>0,05)$.

Sonuç: Bu sonuçlar 18F-FDG SUV maks değerlerinin erken dönemde steril ve enfekte apse arasındaki ayrım için yararlı olabileceğini öne sürmektedir. Ayrıca ekipmanların ve işaretli ajanların lokal olarak temin edilmesi enfeksiyon enflamasyon ayrımında 18F-FDG-PET görüntüleme yönteminin hızlı tanı yöntemi olmasını sağlar.

Anahtar kelimeler: Apse, enfeksiyon, enflamasyon, S. aureus, terebentin, pozitron emisyon tomografisi/bilgisayarlı tomografi, 18F-2'-deoksi-2-fluoro-d-glukoz, sıçan

\section{Introduction}

Detecting the presence and identifying the localization of infection and inflammation have primary importance for implementation of proper treatment and patient followup $(1,2,3,4,5,6,7)$. Nuclear medicine offers powerful noninvasive imaging techniques for visualization of infection and inflammation-related disorders by imaging the whole body, thus enabling determination of both the localization and extent of inflammatory foci $(8,9)$. Various methods have been developed that display different stages of the inflammatory response. Many radiopharmaceuticals have been evaluated extensively in both preclinical and clinical studies as potential diagnostic agents to identify the sites of infection $(10,11,12,13)$. Although there are several imaging agents, only a few of them are being used in routine clinical practice. There is a definite role of 18F-2'-deoxy-2-fluorod-glucose (18F-FDG) in assessing disease extent, disease activity in patients with infection and inflammation, and evaluation of response to treatment $(6,14)$. The high tissue radioactivity after administration of 18 F-FDG corresponds to increased glucose uptake and consumption through the hexose monophosphate shunt, which is the main source of energy for chemotaxis and phagocytosis (7,15). 18F-FDG, an analog of glucose, is taken up by living cells via cell membrane glucose transporters and subsequently it is phosphorylated with hexokinase inside most cells. Activation of phagocytes, also known as respiratory burst activation, lead to increased 18F-FDG uptake (10). In sterile inflammation, administered $18 \mathrm{~F}-\mathrm{FDG}$ is mainly taken up by neutrophils and macrophages $(6,15)$. A high degree of 18F-FDG uptake is detected in neutrophils during the acute phase of inflammation, while macrophages and polymorphonuclear leukocytes uptake 18F-FDG during the chronic phase $(1,6,11,16)$. $18 \mathrm{~F}-\mathrm{FDG}$ is phagocytized by macrophages and phagocytic cells via d-glucose transporter. Through glycolysis, 18F-FDG is phosphorylated by hexokinase resulting in 18F-FDG-6 phosphate. Positron emission tomography (PET) imaging can be used alone or in conjunction with computed tomography (CT) in diagnosing and management of therapy planning in a variety of disorders (9).

The use of PET/CT represents the new generation in diagnostic modality. PET imaging detects an increase in metabolic activity while $\mathrm{CT}$ provides anatomic correlation $(15,16,17,18)$. Inflammatory cells have an increased positive expression of glucose transporters and growth factors, which affect the affinity of these transporters for deoxyglucose. Due to structural analogy, 2-deoxyglucose 18F-FDG is uptaken at the site of infection at a high level depending on the rate of glycolysis. 18 F-FDG is carried into the cells by the glucose transporters. In case of infection and inflammation, leukocyte activation occurs and glucose is used in the activation as an energy source. Glucose transporter receptors are stimulated by uptake of glucose and its analogues $(17,19)$.

The aim of this study is to evaluate the development of infection and inflammation, as well as to monitor sterile and infected abscesses in rats by using 18F-FDG-PET/CT.

\section{Materials and Methods}

All animals were treated in accordance with the protocols approved by the Animal Care and Use Committee of the University. The designed study was conducted at the animal care facility of the Faculty of Medicine, Dokuz Eylül University.

In this study, sterile abscess was induced by using turpentine and infected abscess was induced by using Staphylococcus aureus ATCC 25923 strain on rats. Three groups of rats were used for imaging as sterile, infected, and control groups. Another group of rats were used to remove the abscess tissue to compare number of living organism with standard uptake value (SUV). They were male White Wistar Rats, clinically healthy animals of 150$220 \mathrm{gr}$ body weight. 


\section{Bacterial Strain and Rat Model for Abscess Formation}

S. aureus strain (ATCC 25923) was grown in 5-10\% sheep blood agar (Salubris, USA) after incubating overnight at $37^{\circ} \mathrm{C}$.

One loop of the $S$. aureus colonies was suspended in Mueller Hinton broth (mhb) containing tube to obtain $10^{7}$ colony-forming units (CFU)/mL.

The animals were anesthetized by intraperitoneal administration of xylazine, $5 \mathrm{mg} / \mathrm{kg}$ and ketamin, $35 \mathrm{mg} / \mathrm{kg}$. For infected abscess formation on rats $(n=14)$, S. aureus 0.5 $\mathrm{mL} 10^{7} \mathrm{CFU} / \mathrm{mL}$ was inoculated in the right arm of the rats subcutaneously. For sterile abscess formation on rats $(n=7)$ 0.2-0.4 mL turpentine (Sigma-Aldrich) was injected into the right arm of the rats subcutaneously. In the control group $(\mathrm{n}=6), 0.5 \mathrm{~mL} 0.9 \% \mathrm{NaCl}$ was injected into the right arm of the rats subcutaneously. Following each imaging, an abscess of a rat was removed in the another $S$. aureus group and living bacterial organisms were counted in the excised tissue.

\section{Positron Emission Tomography/Computed Tomography Imaging of Rats}

A preliminary study was performed to optimize imaging time depending on abscess formation. First day image was acquired 24 hours after inoculation of $S$. aureus and turpentine. 18F-FDG (37 MBq) was injected intravenously via the tail vein. Prior to $18 \mathrm{~F}-\mathrm{FDG}$ injection, rats fasted for 4 hours and were well hydrated. Imaging was performed using PET/CT (PHILIPS Gemini TF), beginning one hour after injection of 18F-FDG on the first day for five days with an interval of twenty-four hours. 18F-FDG rat imaging was done with two-minute bed positions. On the first day, imaging was performed at the first and second hours after injection of 18F-FDG to obtain optimum imaging time. Non-diagnostic CT images were obtained (90 $\mathrm{kVp}$ and $30 \mathrm{mAs}$, with a thickness slice of $2 \mathrm{~mm}$, the rotation time was $0.5 \mathrm{sec}, 39 \mathrm{~mm} / \mathrm{sec}$ bed speed, $512 \times 512$ matrix).

\section{Image Analysis}

PET/CT images were visually and semi-quantitatively assessed. For semi-quantitative analysis of the PET images, a region of interest (ROI) was drawn around the abscess area on the right arm. In the control group, a ROI was drawn around a similar area as the background on the right arm. SUV max was obtained from the images for evaluation of glucose metabolism of infection and inflammation detected by 18F-FDG-PET/CT.

The SUV $V_{\text {max }}$ of 18 F-FDG uptake were calculated on abscess sites by using the formula:

SUV=Tissue concentration $(\mathrm{Bq} / \mathrm{g}) /[$ injected dose $(\mathrm{Bq}) /$ body weight $(\mathrm{g})$ ]

\section{Results}

Twenty-four hours after inoculation of $S$. aureus or turpentine, swelling was apparent in the abscess site. A soft tissue infection developed on the right arm within twentyfour hours after bacterial inoculation. Swelling and redness of the abscess area were apparent in all rats. Abscess sites were visualized by 18F-FDG-PET/CT. A higher abscess/ background ratio was detected at the first hour compared to the second hour after injection of 18F-FDG. Imaging time was chosen as the first post injection hour for the following days.

The initial SUV max for S. aureus was $3.9 \pm 0.9$ on the first day, while it was $2.2 \pm 0.8$ for sterile abscess and $1.2 \pm 0.5$ for control group rats. The first day $S_{\text {max }}$ on the second

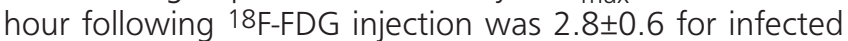
abscess, $1.9 \pm 0.9$ for sterile abscess, and $1.2 \pm 0.09$ for control group. During the following two days, although activity involvement decreased at $S$. aureus it was still higher than involvement in turpentine abscess. There were statistically significant differences between $S$. aureus and sterile abscess, and between sterile abscess and control group as SUV max for the first three days $(p<0.05)$. On the fourth and fifth days, there was no statistically significant difference between $S$. aureus and sterile abscess, and between sterile abscess and control group ( $p>0.05$ ).

It was observed that SUV max of infected abscess was higher than that of sterile abscess in all images during the first three days. CFUs per milliliters (CFU/mL) in excised abscess tissue was $10^{4} \mathrm{CFU} / \mathrm{mL}, 10^{3} \mathrm{CFU} / \mathrm{mL}, 10^{2} \mathrm{CFU} / \mathrm{mL}$ in the first, second and third days, respectively. There was no living organism at the fourth and fifth days. A correlation was detected between 18F-FDG activity and number of living microorganisms in excised abscess tissue.

Figures $1 \mathrm{a}, 1 \mathrm{~b}, 2 \mathrm{a}, 2 \mathrm{~b}$ display $18 \mathrm{~F}-\mathrm{FDG}$ images of sterile and infected abscess in rats.

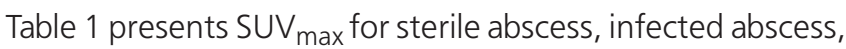
and control rats as well as the quantity of living organisms.

\section{Discussion}

It is clinically important to distinguish infection from inflammation $(6,14)$. Abscess is a life threatening and important complication of inflammation or major surgery $(19,17)$. Most infectious and inflammatory foci can be visualized accurately with radiolabeled autologous leukocytes. In vitro labeled leukocyte imaging is the gold standard for imaging most infection. However, preparation of this radiopharmaceutical is laborious, time consuming and requires handling of potentially contaminated blood (4). New agents are being developed that could potentially differentiate between infection and non-microbial inflammation. In addition to these, it is suggested that 18F-FDG-PET imaging can be used to visualize inflammatory foci when a high spatial resolution is required (1).

Kumar et al. (20) compared 67Ga Citrate SPECT and $68 \mathrm{Ga}$ Citrate PET in $S$. aureus infection in the rat model. They concluded that ${ }^{68} \mathrm{Ga}$ Citrate PET is a faster imaging method 
as $68 \mathrm{Ga}$ has a half-life of 68 minutes compared to 78.3 hours for $67 \mathrm{Ga}$. Yamada et al. (21) studied 18F-FDG uptake and its distribution in turpentine induced inflammatory tissue on male Donryu rats. They showed that the uptake in inflammatory tissue increased gradually upto 60 minutes and then decreased. Our study also showed an increased activity within 60 minutes followed by a decreased activity 120 minutes after injection of 18F-FDG. They reported an increasing activity which peaked on the 4 day after inoculation followed by a slow down. Our study detected the highest 18 F-FDG activity a day after turpentine inoculation. In our study, there was also a correlation between 18F-FDG activity and quantity of living microorganisms in excised abscess tissue. These differences may be due to the rat's immune tolerance.

Kaim et al. (22) studied 18F-FDG and 18F-FET in an acute phase abscess model. Their histological study showed increased 18F-FDG uptake that corresponded to cellular inflammatory infiltrates, mainly consisting of granulocytes. The necrotic abscess center and the second necrotic tissue layer were characterized by decreased 18F-FDG uptake. They documented a marked increase in 18F-FDG uptake at the site of infection, which could be attributed to activated granulocytes and macrophages. In their study, 18F-FET uptake was low in inflammatory infiltrates consisting of neutrophil, granulocytes and macrophages. They interpreted this

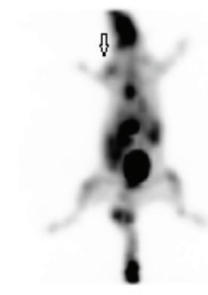

a
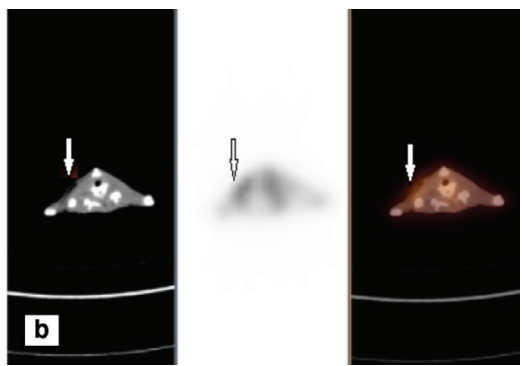

Figure 1. Sterile abscess imaging in rats by using ${ }^{18} \mathrm{~F}-2$ '-deoxy-2-fluorod-glucose positron emission tomography/computed tomography, (a) 3D MIP image, (b) Transverse cross-sectional images, computed tomography, positron emission tomography and fusion images finding as either low uptake in the bacterial area may be lacking bacterial uptake by $18 \mathrm{~F}-\mathrm{FET}$ or small number of living bacteria in the infection area. On the other hand, our study demonstrated that there was a correlation between bacterial load and 18F-FDG uptake rate. A greater bacterial load in the excised abscess yielded a higher SUV.

Sugawara et al. (23) compared 18F-FDG, thymidine, L-methionine, ${ }^{67} \mathrm{Ga}$ Citrate and $125 \mathrm{I}-\mathrm{HSA}$ in sites of bacterial infection in rats infected with $E$. coli. Their auto-radiographic study detected the highest 18F-FDG uptake in the inflammatory area of cell infiltration surrounding the necrotic region. In their study, 18F-FDG showed much higher uptake values than $67 \mathrm{Ga}$ Citrate or 125I-HSA. They reported lower methionine and thymidine accumulation in the infectious foci than 18F-FDG. In their bacterial model, an abscess was formed and the necrotic area showed slightly higher $18 \mathrm{~F}-\mathrm{FDG}$ uptake than the surrounding edematous muscle, while the center of the abscess in turpentine model showed very low 18F-FDG uptake. In our study, 18F-FDG uptake in the bacterial site was higher than the inflammation site. It has been reported that abscess-forming bacteria utilize glucose as an energy source using various pathways. The lack of any 18F-FDG uptake could be attributed to a low number of inflammatory cells, lack of granulation tissue, or absence of microorganisms.
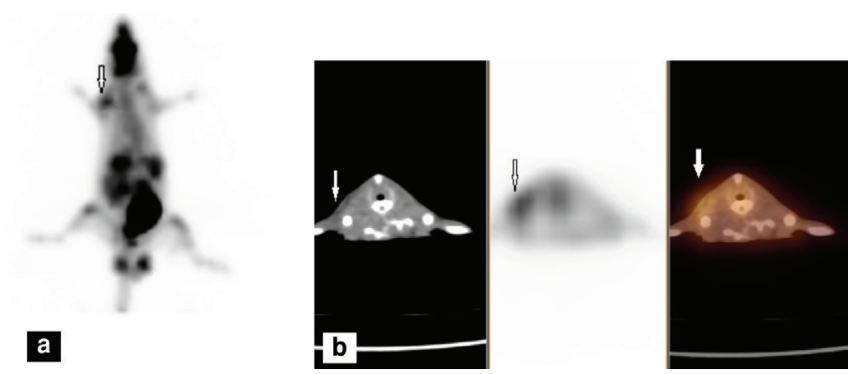

Figure 2. Infected abscess imaging in rats by using 18F-2'-deoxy-2-fluorod-glucose positron emission tomography/computed tomography, (a) 3D MIP image, (b) Transverse cross-sectional images, computed tomography, positron emission tomography and fusion images

Table 1. Maximum standard uptake values for sterile abscess, infected abscess and control and number of living organism

\begin{tabular}{|c|c|c|c|c|}
\hline \multicolumn{5}{|c|}{ SUV $_{\max }$} \\
\hline Imaging times & Infected abscess & Sterile abscess & Control & Living organism CFU/mL \\
\hline First day at one hour & $3.9 \pm 0.9$ & $2.2 \pm 0.8$ & $1.2 \pm 0.5$ & \multirow{2}{*}{$1 \times 10^{4}$} \\
\hline First day at two hour & $2.8 \pm 0.6$ & $1.9 \pm 0.9$ & $1.2 \pm 0.3$ & \\
\hline Second day at one hour & $1.9 \pm 0.2$ & $1.8 \pm 1$ & $0.9 \pm 0.3$ & $1 \times 10^{3}$ \\
\hline Third day at one hour & $1.2 \pm 0.4$ & $0.9 \pm 0.3$ & $0.7 \pm 0.2$ & $1 \times 10^{2}$ \\
\hline Fourt day at one hour & $0.9 \pm 0.5$ & $0.7 \pm 0.3$ & $0.7 \pm 0.3$ & No living organism \\
\hline Fifth day at one hour & $0.8 \pm 0.4$ & $0.7 \pm 0.2$ & $0.7 \pm 0.2$ & No living organism \\
\hline
\end{tabular}

CFU: Colony-forming units, Suv max $_{\text {: }}$ Maximum standard uptake 
Dumarey et al. (24) used 18F-FDG labeled leukocytes for imaging of inflammation. They found high sensitivity and specificity rates for the diagnosis of infection. They concluded that due to 18 F-FDG uptake in the brain, the genitourinary tract and variable activity in the myocardium, bone marrow, stomach and bowel, 18F-FDG-PET had poorer diagnostic performance compared with labeled leukocytes for the detection of infection in these sites. We also observed major uptake in these organs. We agree with Dumarey et al. (24) that the diagnostic performance of 18F-FDG imaging in infection of these sites is poor. However, leukocyte labeling procedure is time consuming and needs careful handling process.

Pellegrino et al. (25) carried out a study to compare the relative uptakes of $18 \mathrm{~F}-\mathrm{FDG}$ and of $18 \mathrm{~F}-\mathrm{FDG}$ labeled WBCs in sterile and septic inflammation foci in an animal model. Their results showed that $18 \mathrm{~F}-\mathrm{FDG}-\mathrm{WBC}$ PET imaging had a greater performance versus 18F-FDG in the sterile inflammation model as well as in E.coli and P. aeruginosa septic models. Jamar et al. (26) emphasized that it should be kept in mind that the choice between 18 F-FDG imaging and an alternative technique depends on the need for rapid diagnosis and local availability of required equipment and labeled agents.

In our study, the highest 18F-FDG activity was observed on the first day following inoculation in the infection and the inflammation sites, and then the activity decreased day by day. This could be related to the rapid metabolic activity in fast recovering rats. On the fourth and fifth days, 18F-FDG activity was equal to that of the controls. We compared activity rates according to bacterial load by excising tissue. It was seen that bacterial load and 18F-FDG uptake values correlated with infection severity. In this study, the imaging was performed by $\mathrm{PET} / \mathrm{CT}$ that is designed for human body imaging, if imaging studies had been obtained with small animal imaging device (microPET/CT) resolution of the images would have been higher than the presented images.

\section{Conclusion}

Inflammatory and infected tissues utilize glucose as energy source for chemotaxis and phagocytosis. Therefore, the accumulation of 18F-FDG as a glucose analog can be used for diagnosis of infection and inflammation. Sterile and infected abscess differentiation can be evaluated by imaging with 18F-FDG-PET at early phase. The value of $S U V_{\text {max }}$ explores correlation between sterile abscess and infected abscess. 18F-FDG-PET is also a useful technique to understand the extent of the infection and inflammation process. In addition to PET imaging method with 18F-FDG has the possibility of rapid diagnosis and easier with the advantage of local availability.

\section{Ethics}

Ethics Committee Approval and Informed Consent: All animals were treated in accordance with the protocols approved by the Animal Care and Use Committee of the University. The designed study was conducted at the animal care facility of the Faculty of Medicine, Dokuz Eylül University.

Peer-review: Externally peer-reviewed.

\section{Authorship Contributions}

Surgical and Medical Practices: T.E., M.S.E., M.K., G.O., H.D., Concept: T.E., M.S.E., M.K., G.O., H.D., Design: T.E., M.S.E., M.K., G.O., H.D., Data Collection or Processing: T.E., M.S.E., M.K., G.O., H.D., Analysis or Interpretation: T.E., M.S.E., M.K., G.O., H.D., Literature Search: T.E., M.S.E., M.K., G.O., H.D., Writing: T.E., M.S.E., M.K., G.O., H.D.

Conflict of Interest: No conflict of interest was declared by the authors.

Financial Disclosure: The authors declared that this study received no financial support.

\section{References}

1. Kumar R, Basu S, Torigian D, Anand V, Zhuang H, Alavi A. Role of modern imaging techniques for diagnosis of infection in the era of 18F-Fluorodeoxyglucose positron emission tomography. Clin Microbiol Rev 2008;21:209-224.

2. Gotthardt M, Bleeker-Rovers CP, Boerman OC, Oyen WJG. Imaging of inflammation by PET, conventional scintigraphy, and other imaging techniques. J Nucl Med 2010;51:1937-1949.

3. Petruzzi, N, Shanthly N, Thakur M. Recent Trends in Soft Tissue Infection Imaging. Semin Nucl Med 2009;39:115-123.

4. Vangu MW. Infection imaging in nuclear medicine Nuclear medicine has a role to play in investigating patients with suspected infection. CME 2013;31:295.

5. Mahfouz T, Miceli MH, Saghafifar F, Stroud S, Jones-Jackson L, Walker R, Grazziutti ML, Purnell G, Fassas A, Tricot G, Barlogie B, Anaissie E, 18F-Fluorodeoxyglucose positron emission tomography contributes to the diagnosis and management of infections in patients with multiple myeloma: a study of 165 infectious episodes. J Clin Oncol 2005;23:7857-7863.

6. Kumar R, RN Murali, Balakrishnan V, Bal C, Malhotra A. FDG-PET imaging in infection and inflammation. IJNM 2006;21:104-113.

7. Elgazzar $\mathrm{AH}$, Elmonayeri $\mathrm{M}$. The pathophysiologic basis of nuclear medicine. Elgazzar AH (ed). Inflammation. Newyork, Springer-Verlag Berlin Heidelberg, 2006;67-89.

8. Bleeker-Rovers CP, Boerman OC, Oyen WJH. Radiolabeled compounds in diagnosis of infectious and inflammatory disease. Curr Pharm Des 2004;10:2935-2950.

9. Love C, Palestro CJ. Radionuclide imaging of infection. J Nucl Med Technol 2004;32:47-57.

10. Goldsmith SJ, Vallabhajosula S. Clinically Proven Radiopharmaceuticals For Infection Imaging: Mechanisms And Applications. Semin Nucl Med 2009;39:2-10.

11. Truluck CA. Inflammation and infection imaging, nuclear medicine technology. J Radiol Nurs 2007;26:77-85.

12. Laverman P, Bleeker-Rovers CP, Corstens FHM, Boerman OC, Oyen WJG. Development of Infection and Inflammation Targeting Compounds Current. Radiopharmaceuticals 2008;1:42-48.

13. Welling M, Feitsma HJ, Calume W, Pauwels EKJ. Detection of experimental infections with 99mtc-Labeled Monoclonal Antibodies Against Tnf-(X And Interleukin-8). Nucl Med Biol 1997;24:649-655.

14. Glaudemans AW, de Vries EF, Galli F, Dierckx RA, Slart RH, Signore A. The Use of 18F-FDG-PET/CT for diagnosis and treatment monitoring of inflammatory and infectious diseases. Clin Dev Immunol 2013;2013:623036. 
15. Burt BM, Hummy JL, Kooby DA, Squirey OD, Mastoridesz S, Larsony SM, Fong Y. Using positron emission tomography with [18F]FDG to predict tumor behavior in experimental colorectal cancer. Neoplasia 2001;3:189-195.

16. A Vera. FDG-PET/CT in the detection of infections and inflammations. Arch Oncol 2012;20:103-106.

17. Rudd JHF, Narula J, Strauss HW, Virmani R, Machac J, Klimas M, Tahara N, Fuster V, Warburton EA, Fayad ZA, Tawakol AA. Imaging atherosclerotic plaque inflammation by fluorodeoxyglucose with positron emission tomography. J Am Coll Cardiol 2010;55:25272535.

18. Coker CO. Flurodeoxyglucose positron emission tomography: a new technique to evaluate infectious processes. Chapter 2008;42:217-220.

19. Sabah S. Imaging infection and inflammation in children with 18F-FDG-PET and 18F-FDG-PET/CT. J Nucl Med Technol 2011;39:179182.

20. Kumar V, Boddeti DK, Evans SG, Angelides S. 68Ga-Citrate-PET for diagnostic imaging of infection in rats and for intra-abdominal infection in a patient. Curr Radiopharm 2012;5:71-75.

21. Yamada S, Kubota K, Kubota R, Ido T, Tamahashi N. High accumulation of fluorine-18-fluorodeoxyglucose in turpentineinduced inflammatory tissue. J Nucl Med 1995;36:1301-1306.
22. Kaim AH, Weber B, Kurrer MO, Westera G, Schweitzer A, Gottschalk J, Von Schulthess GK, Buck A. 18F-FDG and 18F-FET uptake in experimental soft tissue infection. Eur J Nucl Med 2002;29:648654.

23. Sugawara Y, Gutowski TD, Fisher SJ, Brown RS, Wahl RL. Uptake of positron emission tomography tracers in experimental bacterial infections: a comparative biodistribution study of radiolabeled FDG, thymidine, L-methionine, 67Ga-citrate, and 125I-HSA. Eur J Nucl Med 1999;26:333-341.

24. Dumarey $N$, Egrise $D$, Blocklet $D$, Stallenberg $B$, Remmelink $M$, Marmol V, Simaeys GV, Jacobs F, Goldman S. Imaging infection with 18 F-FDG-labeled leukocyte PET/CT: initial experience in 21 patients. J Nucl Med 2006;47:625-632.

25. Pellegrino D, Bonab AA, Dragotakes SC, Pitman JT, Mariani G, Carter EA. Inflammation and infection: imaging properties of 18F-FDGlabeled white blood cells versus 18F-FDG. J Nucl Med 2005:46:15221530.

26. Jamar F, Buscombe J, Chiti A, Christian PE, Delbeke D, Donohoe KJ, Israel O, Martin-Comin J, Signore A. EANM/SNMMI Guideline for 18F-FDG use in inflammation and infection. J Nucl Med 2013;54:647658. 